\title{
Geogenic and Anthropogenic Chromium Contamination in Groundwater in an Ophiolitic Area, Northeastern Iran
}

\author{
Abdolreza Jafarian¹, Susan Jafarian²,* \\ ${ }^{1}$ Geology Department, Islamic Azad University (IAU), Shahrood Branch, Iran \\ ${ }^{2}$ Medicine Department of Pediatrics, Islamic Azad University (IAU), Shahrood Branch, Iran
}

Copyright $@ 2017$ by authors, all rights reserved. Authors agree that this article remains permanently open access under the terms of the Creative Commons Attribution License 4.0 International License

\begin{abstract}
Geology of Iran shows an ophiolitic belt around the central Iran micro-continent. One of the main ophiolite suites, with ca. $100 \mathrm{~km}$ long and $15 \mathrm{~km}$ wide, located northeastern Iran as Sabzevar ophiolite suite. Ultramafic rocks of this ophiolite suite, display a high concentration of chromium (1000-3000 $\mathrm{ppm}$ ) as a compatible element, especially in pyroxene group minerals. Average Chromium content of this ophiolite suite in peridotites is $2558_{\mathrm{ppm}}$, with maximum $4525_{\mathrm{ppm}}$ (in pyroxenite) and minimum $832_{\mathrm{ppm}}$ (in dunite). Dunite layers lie underneath of these ultramafic rocks, containing chromite lenses $\left(\mathrm{FeCr}_{2} \mathrm{O}_{4}\right)$ with 20.56 wt $\% \mathrm{Cr}_{2} \mathrm{O}_{3}$. Today, about 10 active mining sites excavate ultramafic rocks for chromite ore mineral and altered ultramafic rocks, serpentinite, dump as unconsolidated gangue materials along stream pathways. There is an unconfined aquifer just southern of this ophiolite range containing detrital altered ultramafic rocks with the high concentration of chromium minerals. In this study 23 groundwater samples, collected from unconfined serpentinite alluvium aquifer that shows cumulative increasing $\mathrm{Cr}$ towards south because of increasing residence time, and much more water-rock interactions. Total $\mathrm{Cr}$ concentrations in this aquifer are from 12 to $61 \mu \mathrm{g} / \mathrm{l}$, higher than normal level of $\mathrm{Cr}$ mentioned by WHO $(2 \mu \mathrm{g} / \mathrm{l})$. On the other hand, discharging of chromite mine and mineral processing site, contaminate one of drinking well at Forumad village up to $61 \mu \mathrm{g} / \mathrm{l}$ of total chromium.
\end{abstract}

Although trivalent $\mathrm{Cr}$ is an essential nutrient, in oxidation conditions with increasing $\mathrm{Eh}$ and $\mathrm{pH}$, it changes to chromate $\left(\mathrm{CrO}_{4}^{-2}\right)$ and dichromate $\left(\mathrm{Cr}_{2} \mathrm{O}_{7}{ }^{2-}\right)$ as dissolved anions which will be toxic and carcinogenic in groundwater. Based on California EPA Office of Environmental Health Hazard Assessment (OEHHA), $7.2 \%$ of total $\mathrm{Cr}$ is hexavalent. Recent information indicates that hexavalent chromium varies from $50 \%$ to $90 \%$ of the total chromium in many water supplies.

Keywords Groundwater Contamination, Hexavalent Chromium, Serpentinite Aquifer, Chromite Mine, Sabzevar Ophiolite, Carcinogenic Chromium

\section{Introduction}

Serpentinites or altered ultramafic rocks are distributed around central Iran and always associated with ophiolite complexes. One of the biggest ophiolite suites located in north-eastern Iran called Sabzevar ophiolite, ca. $200 \mathrm{~km}$ long and maximum $20 \mathrm{~km}$ wide and $2100 \mathrm{~km}^{2}$ areas (Figure 1). 


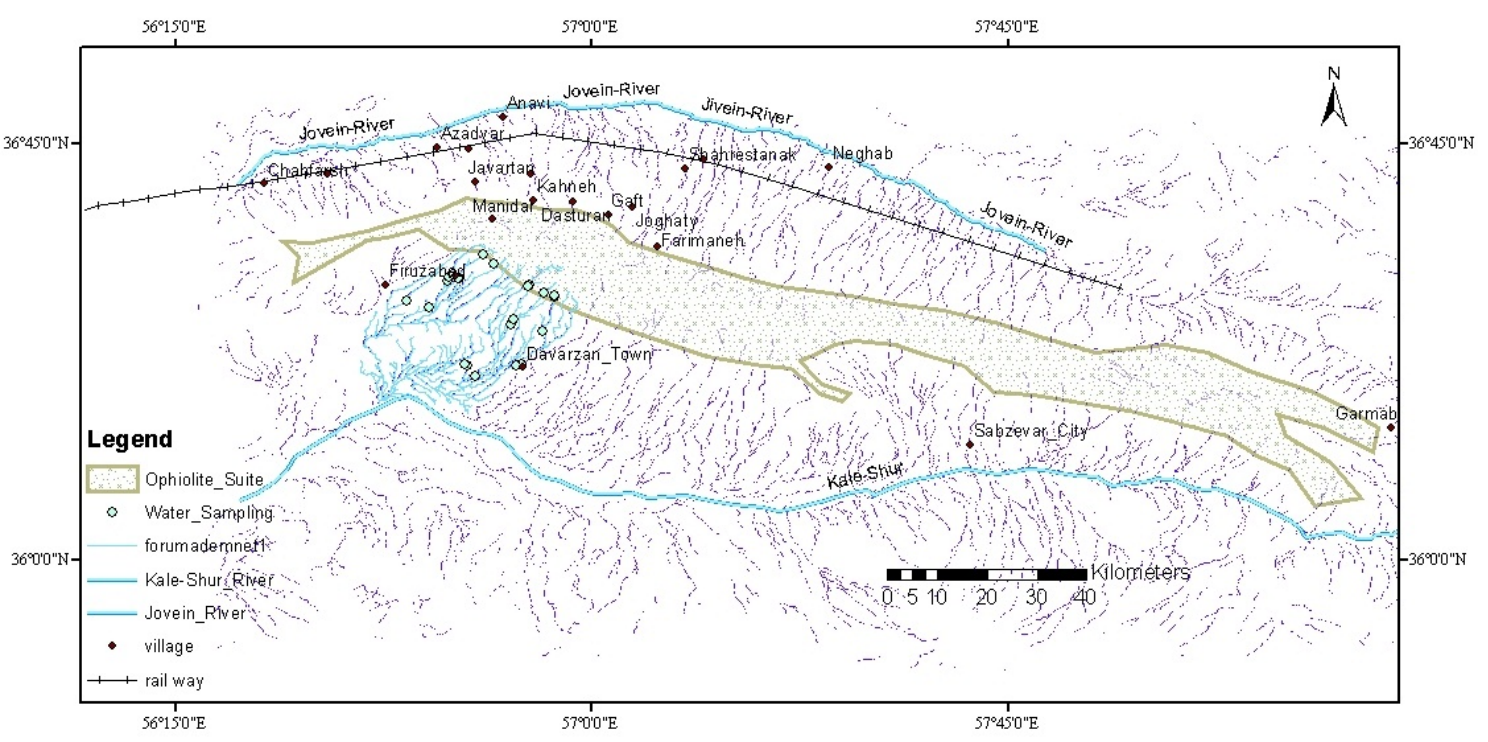

Figure 1. Sketch map of Sabzevar ophiolite suite (modified maps of Geology map of Sabzevar [1] and Geology map of Jajarm [2]) and its drainage systems, delineated by TauDEM [3], originated from highland ophiolite, discharged on two seasonal and temporary river basins located northern part and southern part of this ophiolite range, called Jovein River and Kale-Shur River respectively

Chromium in these ultramafic rocks exists as a trace element especially in pyroxene group minerals, olivine, and chlorite, and $\mathrm{Cr}$ as a major element exists in chromite, and spinel minerals. Chromite, ore mineral $\mathrm{Cr}$, in this suite, represents more than $20 \%$ chromium [4]. Whole rock analyses of peridotite show $\mathrm{Cr}$ level from $832_{\mathrm{ppm}}$ to $4525_{\mathrm{ppm}}$ [4]. Alteration and weathering of these rocks generate serpentinite soil and sediments containing high-level $\mathrm{Cr}$ as alluvial fans in southern and northern plains of this highland. Drainage basins wash both sides of this ophiolite suite (Figure 1) and leach $\mathrm{Cr}$ into groundwater. On the other hand, water-rock interaction and oxidation conditions in aquifer dissolve $\mathrm{Cr}(\mathrm{III})$ into $\mathrm{Cr}(\mathrm{VI})$ (Figure 2). The $\mathrm{pE}-\mathrm{pH}$ diagram describes the relative importance of $\mathrm{Cr}(\mathrm{III})$ and $\mathrm{Cr}(\mathrm{VI})$ at equilibrium and the dominant species (Figure 2). As a general rule, $\mathrm{Cr}(\mathrm{VI})$ is expected to predominate in highly oxygenated drinking water or when strong oxidants such as chlorine or even moderately strong oxidants like chloramine are added in water treatment plant. At low $\mathrm{Cr}$ concentrations in typical drinking water conditions $\mathrm{Cr}(\mathrm{VI})$ is present as monovalent $\mathrm{HCrO}_{4}^{-}$below pH 6.5 and divalent $\mathrm{CrO}_{4}{ }^{2-}$ between pH 6.5 to $10[5,6]$. At very low or no oxygen levels, $\mathrm{Cr}(\mathrm{III})$ is the dominant species, which will be in cationic $\left(\mathrm{Cr}^{+3}, \mathrm{CrOH}^{+2}\right.$, or $\left.\mathrm{Cr}(\mathrm{OH})_{2}{ }^{+}\right)$or neutral $\left(\mathrm{Cr}(\mathrm{OH})_{3}\right)$ form depending on the $\mathrm{pH}[5,7]$. $\mathrm{Cr}(\mathrm{III})$ tends to be extremely insoluble $(<20 \mu \mathrm{g} / \mathrm{L})$ between $\mathrm{pH} 7$ and $\mathrm{pH}$ 10 , with minimum solubility at $\mathrm{pH} 8$ of about $1 \mu \mathrm{g} / \mathrm{L}[5]$.

Maximum concentration level (MCL) of total $\mathrm{Cr}$ in drinking water regulated by Canadian Drinking Water Quality [8] National Primary Drinking Water Regulations (NPDWR) [9], and WHO [10], are $50 \mu \mathrm{g} / \mathrm{l}, 100 \mu \mathrm{g} / \mathrm{l}$, and $50 \mu \mathrm{g} / \mathrm{l}$, respectively. Now a day because of the carcinogenic potential of hexavalent chromium, these regulations are subject to change.

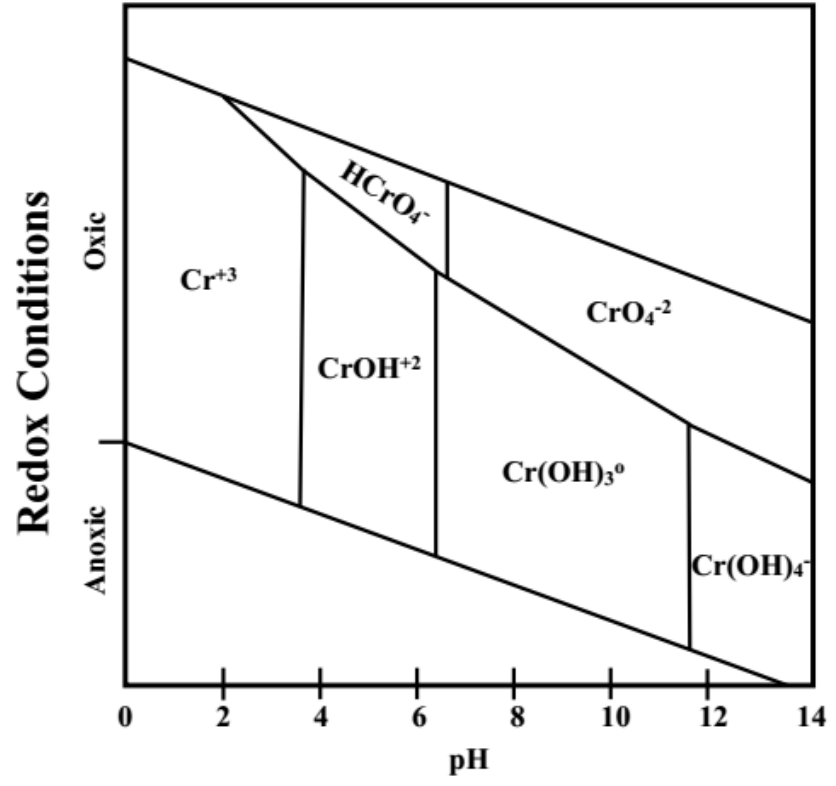

Figure 2. Separation pE-pH diagram for aqueous chromium

The purpose of the present study is to find out total chromium level and $\operatorname{Cr}(\mathrm{VI})$ concentration in water resources of Davarzan area which is the important area because of proximity several active chromite mine, serpentinite and peridotite aquifers alluvium, large watershed basin, and populated area with several village and a big town, Davarzan (Figure 1).

\section{Geological Setting}

Geology of Iran shows an ophiolitic belt around the central Iran micro-continent. One of the main ophiolite 
suite located north-eastern Iran called Sabzevar ophiolite suite. It has ca. $100 \mathrm{~km}$ long and $15 \mathrm{~km}$ wide containing ultramafic, gabbroic, diabasic and volcanic rocks and minor pelagic sediments such as chert and pelagic limestone. There are two large watershed basins with many sub-watershed basins located at the northern and southern part of Sabzevar ophiolite suite. This ophiolite suite with east-west trend shows high elevated mountains, more than $2000 \mathrm{~m}$ high, and divides this area to two huge drainage basins at northern and southern mountain area (Figure 1). Ultramafic rocks contain the high concentration of chromium $\left(1000-3000_{\mathrm{ppm}}\right)$ [4], as a compatible element, especially in pyroxene group minerals. Average Chromium content of Sabzevar ophiolite suite in peridotites is $2558_{\mathrm{ppm}}$ with maximum $4525_{\mathrm{ppm}}$ in pyroxenite, and minimum $832_{\mathrm{ppm}}$ in dunite, and $896_{\mathrm{ppm}}$ in cumulates gabbro. Dunite rocks lay down at the base of harzburgite unit [4], with chromite $\left(\mathrm{FeCr}_{2} \mathrm{O}_{4}\right)$ lenses that represent $20.56 \mathrm{wt} \% \mathrm{Cr}_{2} \mathrm{O}_{3}$. Since 1970, this chromitite horizon has been excavated by several active mines.

\section{Materials and Methods}

Based on EPA [11] procedure for analyzing drinking water, 1-liter plastic bottles were used for collecting water samples. These bottles were washed with detergent, rinsed with tap water, soaked 4 hours in $20 \%(\mathrm{~V} / \mathrm{V})$ nitric acid and finally rinsed with reagent water and dried with air. Electric conductivity (EC) and $\mathrm{pH}$ were measured on site by portable EC meter and $\mathrm{pH}$ meter. To remove micro-particles water samples filtered by $0.2 \mu \mathrm{m}$ filter paper. To extend sample holding time for several weeks, $\mathrm{pH}$ of water samples reduced below 2 by $\mathrm{HNO}_{3}$ and stored in the ice boxes. Total chromium concentration determined by atomic absorption spectrometry (AAS) at Shahrood Science and Technology Park. Cr(VI) converted from total chromium by factors of 0.5 and 0.9 . Watersheds and flow networks were delineated by Terrain Analysis Using Digital Elevation Model, TAUDEM, [3].

\section{Findings}

In this study 23 groundwater samples were collected from wells, springs and qanats, gently sloping underground channel with a series of vertical access shafts, mainly in serpentinite unconfined aquifer applied to drinking water and farming in Forumad watershed area including a town with ca. 50000 population and 10 villages with ca. 4000 population (Table 1). These water resources originate from upstream of the ultramafic mountain range, northern watershed, feeding serpentinite alluvial fan aquifer (Figure 3). These water resources are used for drinking and farming. Total Cr fluctuate between 11.66-60.61 $\mu \mathrm{g} / \mathrm{l}$ with mean of 27.72 $\mu \mathrm{g} / \mathrm{l}$,(Figure 4,Figure 5) EC varies from 190 to $2420 \mu \mathrm{s} / \mathrm{cm}$ with max frequency class $190-747 \mu \mathrm{s} / \mathrm{cm}$, (Figure 6) and $\mathrm{pH}$ changes from 6.5 to 7.5 (Figure 7). Cr vs. $\mathrm{pH}$ diagram indicates maximum $\mathrm{Cr}$ levels follow $\mathrm{pH}$ range of 6.5-7.5 (Figure 8). Collected sample from Forumad city center represents the highest total chromium level $(60.61 \mu \mathrm{g} / \mathrm{l})$.

Table 1. Analyzed water samples from different water resources

\begin{tabular}{|c|c|c|c|c|c|c|c|c|c|}
\hline Town/Village & Resource & Population & Host Rock & †Cr & $\mathrm{Mg}$ & EC & $\mathrm{pH}$ & $¥ \mathrm{Cr}(\mathrm{VI})$ & $\ddagger \mathrm{Cr}(\mathrm{VI})$ \\
\hline & & & & $(\mu \mathrm{g} / \mathrm{l})$ & $(\mathrm{mg} / \mathrm{l})$ & $(\mu \mathrm{s} / \mathrm{cm})$ & & $(\mu \mathrm{g} / \mathrm{l})$ & $(\mu \mathrm{g} / \mathrm{l})$ \\
\hline Abrud & Spring & 2000 & Ultramafic & 11.66 & 23.79 & 370 & 6 & 5.83 & 10.49 \\
\hline Dehno & Qanat & 200 & Serpentinitic alluvium & 13.99 & 68.83 & 1730 & 7 & 6.99 & 12.59 \\
\hline Pahnestan & spring & 10 & Ultramafic & 15.15 & 53.58 & 440 & 7 & 7.58 & 13.64 \\
\hline Abrud & Qanat & 2000 & Ultramafic & 15.15 & 53.93 & 740 & 6 & 7.58 & 13.64 \\
\hline Forumad & Tap water & 5000 & Serpentinitic alluvium & 16.32 & 62.63 & 630 & 6.8 & 8.16 & 14.69 \\
\hline Ghelichi & spring & 20 & Ultramafic & 16.32 & 61.96 & 780 & 6.8 & 8.16 & 14.69 \\
\hline Nahaldan & spring & 1600 & Serpentinitic alluvium & 16.32 & 92.6 & 1470 & 6.5 & 8.16 & 14.69 \\
\hline Nahaldan & Qanat & 1600 & Serpentinitic alluvium & 18.65 & 50 & 690 & 6 & 9.33 & 16.79 \\
\hline Mur & spring & 100 & Ultramafic & 18.65 & 38.98 & 450 & 6.5 & 9.33 & 16.79 \\
\hline Aliabad_Bala & Qanat & 120 & Serpentinitic alluvium & 19.81 & 47.21 & 410 & 6 & 9.91 & 17.83 \\
\hline Kahak & Qanat & 400 & Serpentinitic alluvium & 20.98 & 24.29 & 1240 & 6.8 & 10.49 & 18.88 \\
\hline Aliabad_Bala & Stream & 120 & Ultramafic & 20.98 & 43.15 & 330 & 6 & 10.49 & 18.88 \\
\hline Davarzan & Tap water & 20000 & Serpentinitic alluvium & 23.31 & 39.02 & 480 & 6 & 11.66 & 20.98 \\
\hline Davarzan & well & 20000 & Serpentinitic alluvium & 23.31 & 27.61 & 610 & 7 & 11.66 & 20.98 \\
\hline Forumad & Qanat & 5000 & Serpentinitic alluvium & 27.97 & 29.74 & 450 & 6.8 & 13.99 & 25.17 \\
\hline Kelate_Sadat & spring & 1500 & Serpentinitic alluvium & 30.3 & 23.87 & 800 & 6.5 & 15.15 & 27.27 \\
\hline Estarband & Qanat & 1600 & Serpentinitic alluvium & 30.3 & 22.77 & 190 & 6.5 & 15.15 & 27.27 \\
\hline Bahman_Abad & well & 200 & Serpentinitic alluvium & 39.63 & 67.27 & 2420 & 6.8 & 19.82 & 35.67 \\
\hline Forumad & well & 5000 & Serpentinitic alluvium & 44.29 & 68.69 & 1250 & 6.5 & 22.15 & 39.86 \\
\hline Kahak & Qanat & 400 & Serpentinitic alluvium & 48.95 & 33.92 & 1880 & 7.5 & 24.48 & 44.06 \\
\hline Suiz & Qanat & 300 & Serpentinitic alluvium & 48.95 & 9.98 & 690 & 6.8 & 24.48 & 44.06 \\
\hline Forumad & well & 5000 & Serpentinitic alluvium & 55.94 & 79.73 & 1350 & 7 & 27.97 & 50.35 \\
\hline Forumad & Tap water & 5000 & Serpentinitic alluvium & 60.61 & 79.43 & 1240 & 6.5 & 30.31 & 54.55 \\
\hline
\end{tabular}




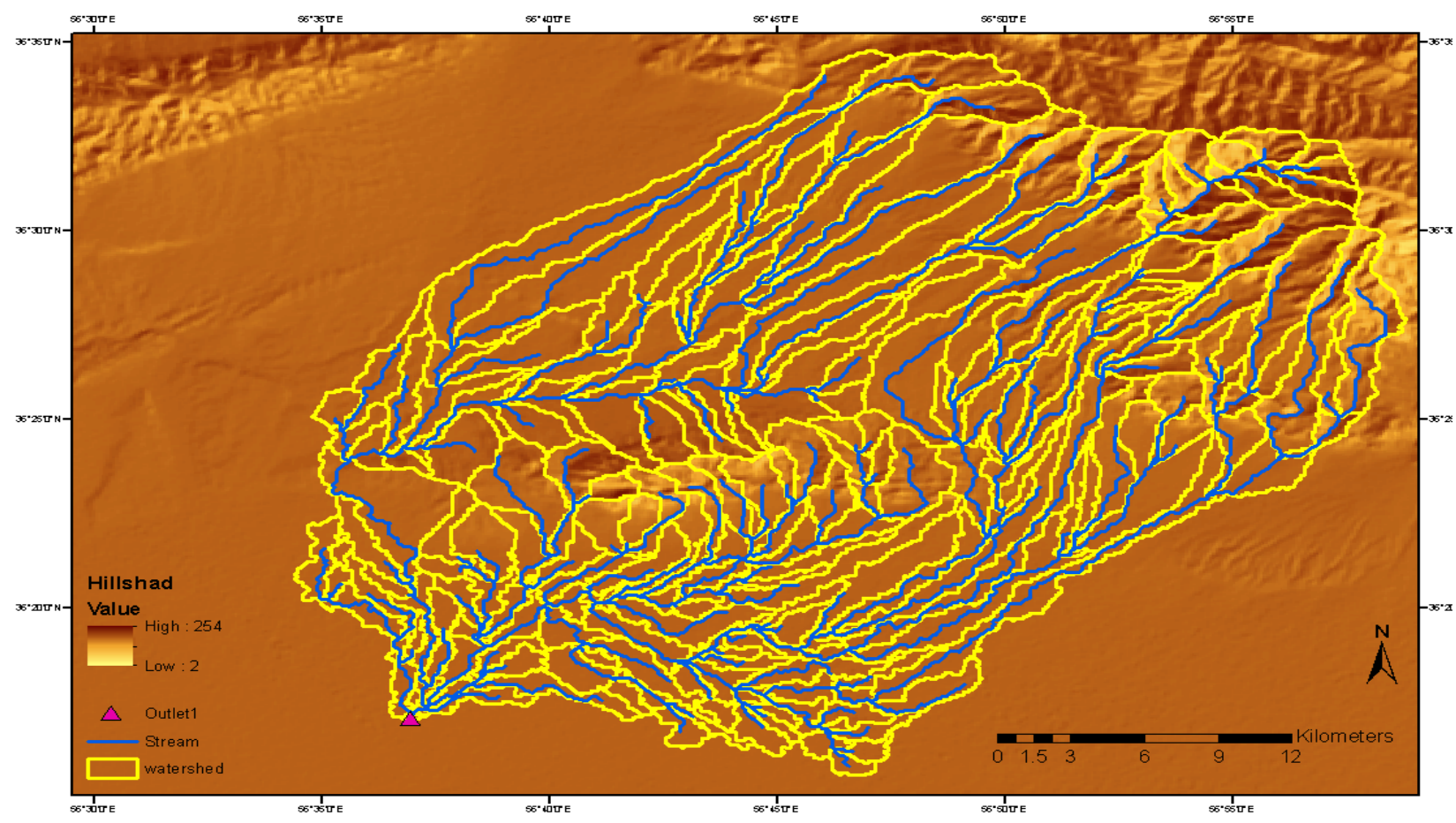

Figure 3. Digital Elevation Map (DEM) representing Forumad single watershed with catchments, and flow networks delineated by TAUDEM[3], charging the unconfined Davarzan aquifer

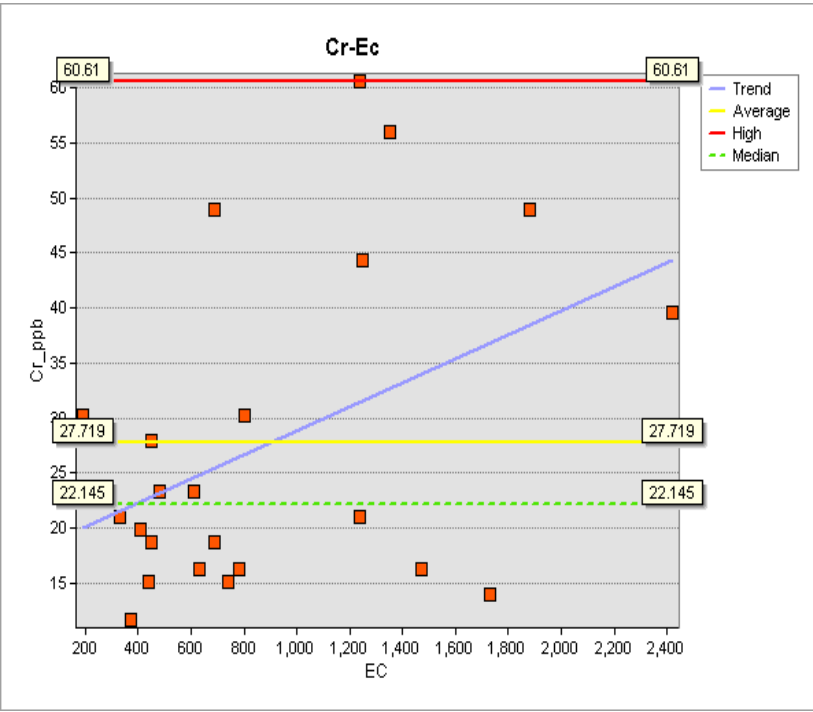

Figure 4. Cr-EC diagram shows the relatively positive correlation between these two factors $\left(R^{2}=0.18\right)$. Red, yellow, and green lines represent highest, mean, and median $\mathrm{Cr}$ concentration in water samples

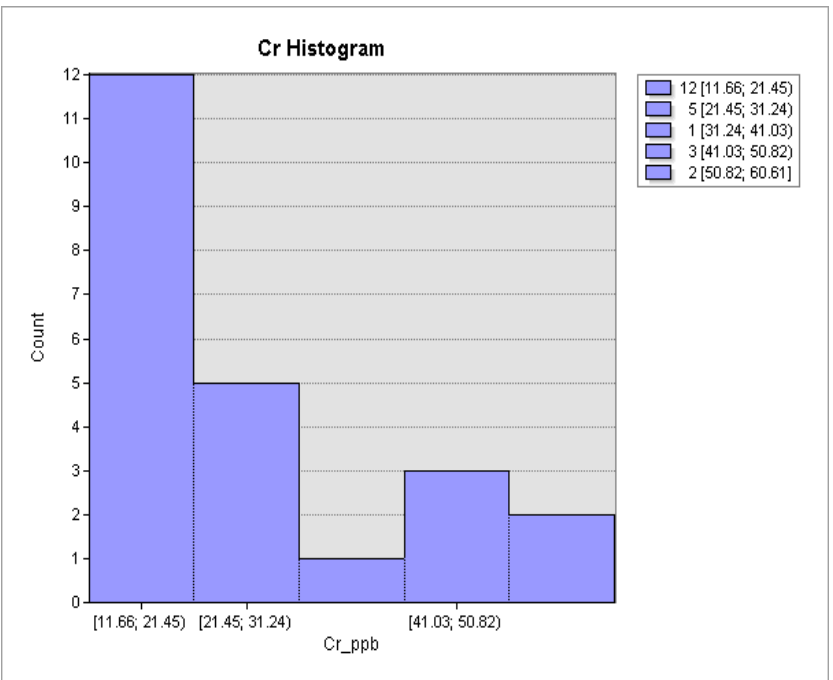

Figure 5. Histogram of $\mathrm{Cr}$ shows high-frequency class is 11.66-21.45ppb 


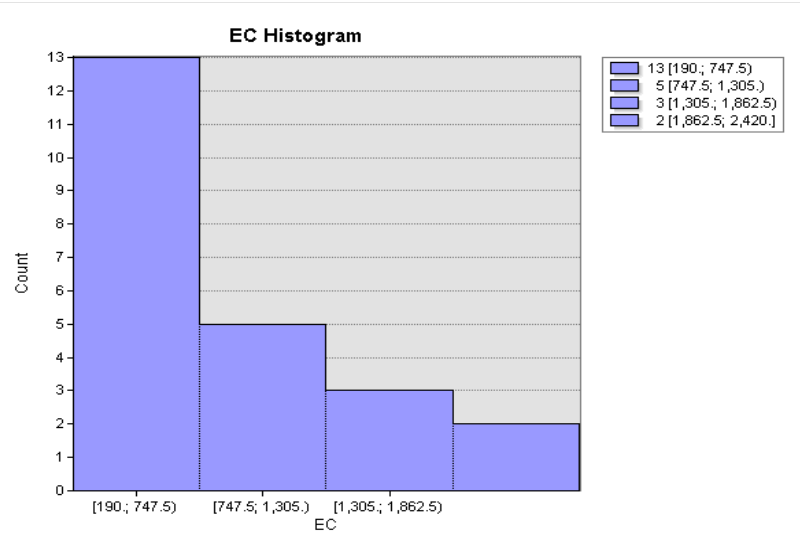

Figure 6. Electrical Conductivity histogram shows high-frequency class at $190-747.5 \mu \mathrm{s} / \mathrm{cm}$

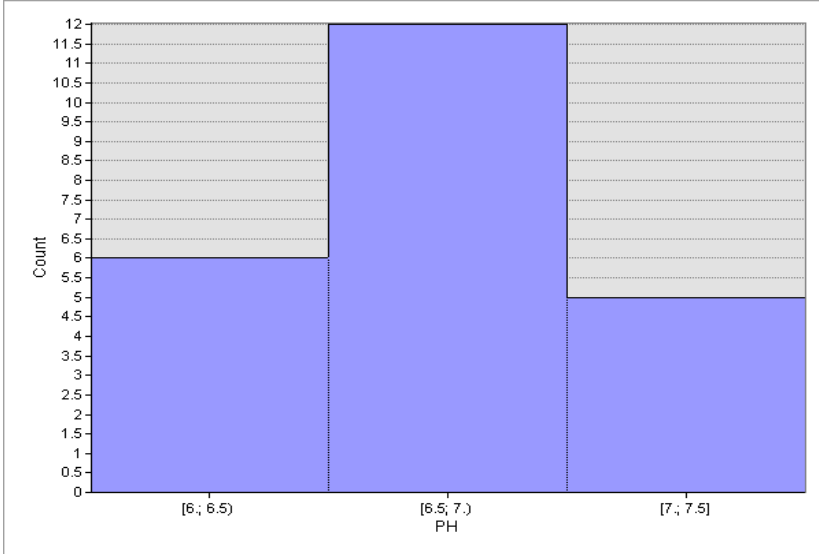

Figure 7. pH histogram shows high-frequency class at 6.5-7.

\section{Discussions and Conclusions}

High-level Chromium in ophiolitic rocks concentrated in mafic minerals such as olivine and pyroxene. Furthermore, spinel group minerals (e.g. Chromite) were genetically generated in ophiolitic rocks and mined for Cr demands. All active chromite districts are mined as open pit and their gangue plus ore minerals are dumped near the mine site especially along stream-net and natural drainage basin. In the southern part of this area, there is a large watershed basin (Figure 3) which charge unconfined aquifers containing alluvial rock originated from northern ophiolitic rocks and chromite mines. Water-rock interaction in these aquifers geochemically influences on groundwater (Figure 9) which is pumped for drinking and farming demands. These Water resources are reserved into the unconfined aquifers with serpentinite and peridotite host rocks containing high-level Cr. Chromium concentration in these ultramafic rocks is $\sim 1603_{\mathrm{ppm}}$ in harzburgite, $\sim 832_{\mathrm{ppm}}$ in dunite, $3271_{\mathrm{ppm}}$ to $4525_{\mathrm{ppm}}$ in pyroxenite [4]. Chromite as the main $\mathrm{Cr}$ mineral contains $60 \mathrm{wt} \%$ chromium. Chromium in mentioned rocks and associated minerals is trivalent. Water-rock interaction in theses oxic unconfined aquifers dissolve $\mathrm{Cr}$ bearing minerals and generate high concentration soluble chromium (Figure 2) (Table 1). Recent studies, however, have shown no harmful effects from low $\mathrm{Cr}(\mathrm{III})$ in the diet and there is no known biological mechanistic function for $\mathrm{Cr}(\mathrm{III})$ in cells calling into questions whether $\mathrm{Cr}(\mathrm{III})$ is truly an essential nutrient [13].

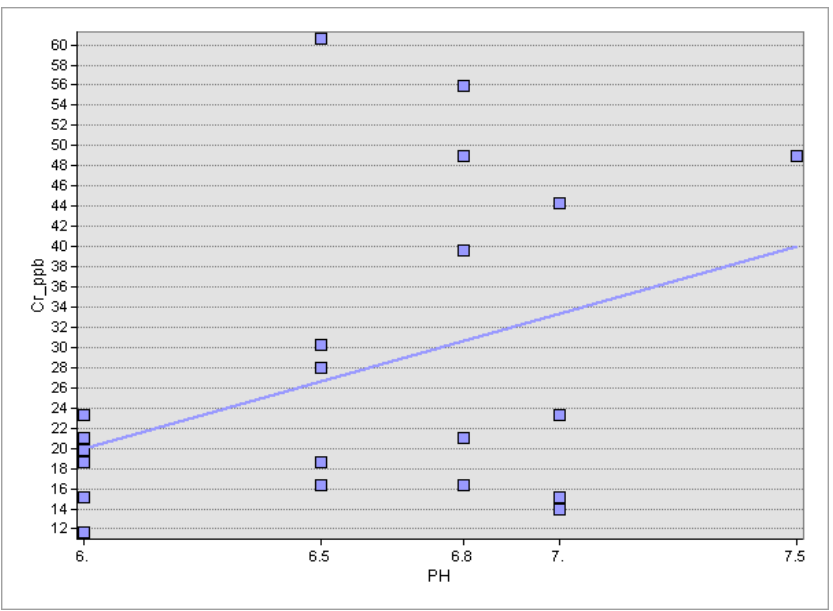

Figure 8. $\mathrm{Cr}-\mathrm{pH}$ diagram shows fairly positive correlation, $\mathrm{R}^{2}=013$ 


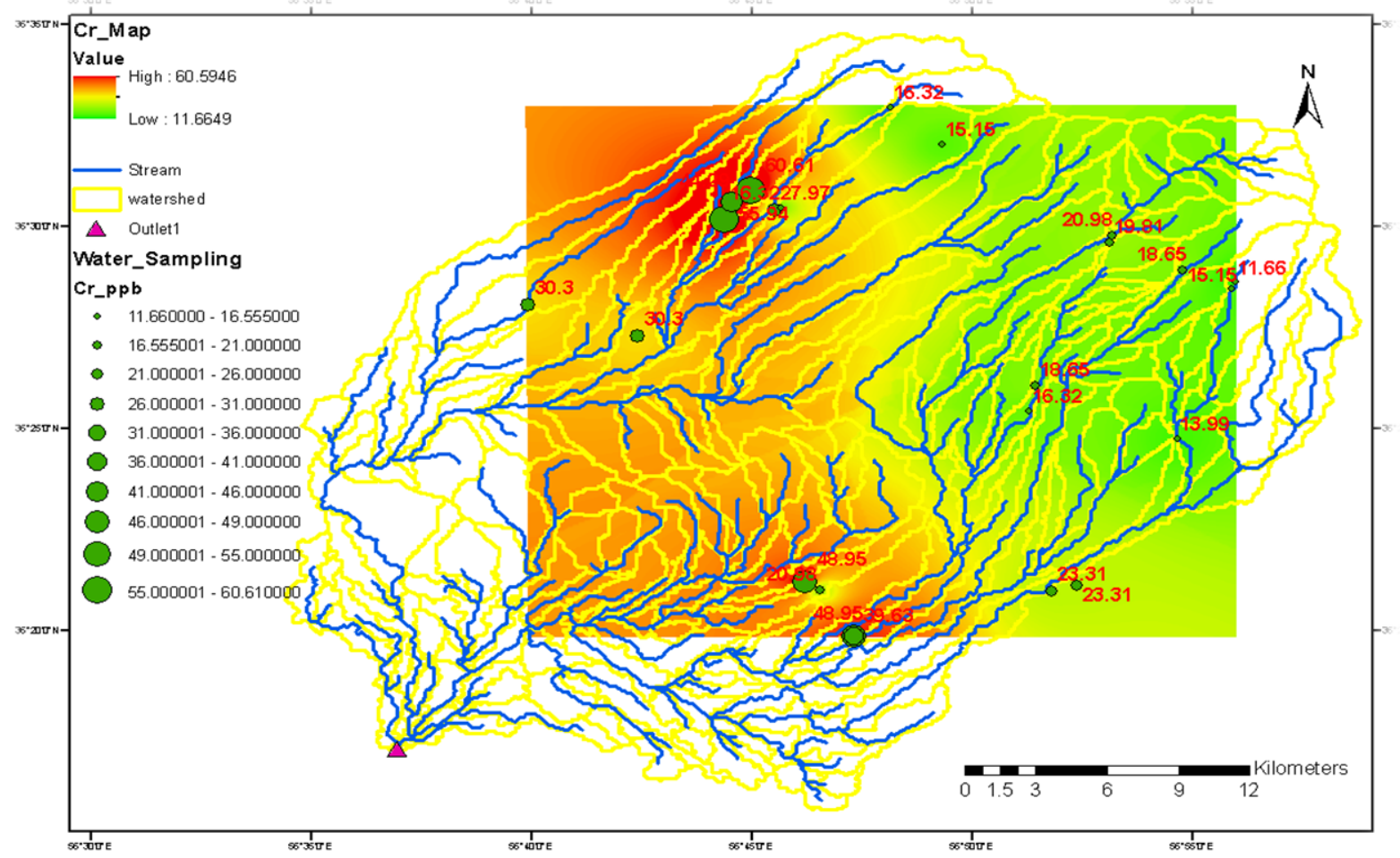

Figure 9. Raster map of distribution chromium concentration see text for details

In a given water sample, $\mathrm{Cr}(\mathrm{III})$ can be present in five forms (Figure 10): 1) as soluble $\mathrm{Cr}(\mathrm{III})$ species, 2) as a precipitated $\mathrm{Cr}(\mathrm{OH})_{3}$ solid, 3) sorbed to the surface of $\mathrm{Fe}(\mathrm{OH})_{3}$ and other oxides, 4) "fixed" inside oxides in a form that is relatively inaccessible from solution, and 5) complexed with natural organic matter (NOM) such as humic and fulvic acids [14] Although $\mathrm{Cr}(\mathrm{VI})$ can undergo similar reactions, it is much more likely to remain soluble. If the iron hydroxide does not dissolve, the models predict that $\mathrm{Cr}(\mathrm{III})$ will be virtually $100 \%$ sorbed over the range from $\mathrm{pH} 6$ to 11 (Figure 11).

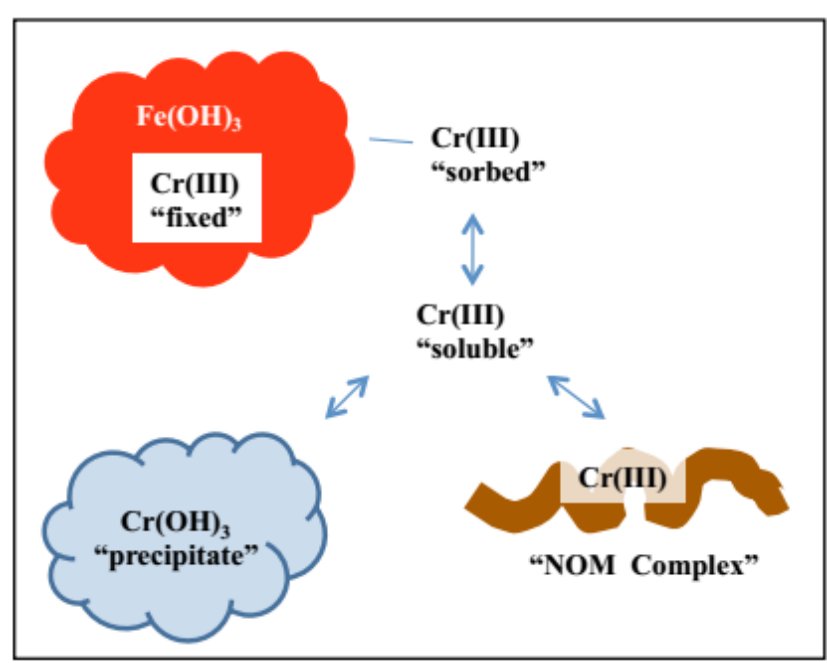

Figure 10. Soluble $\mathrm{Cr}(\mathrm{III})$ in water, see text for explanation [10]

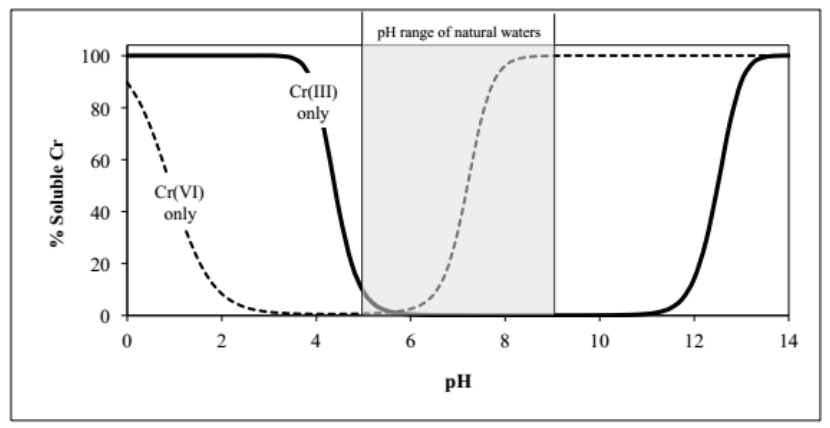

Figure 11. Model prediction of soluble $\mathrm{Cr}(\mathrm{III})$ and $\mathrm{Cr}(\mathrm{VI})$ in a drinking water sample in the presence of iron particles. Conditions: $\operatorname{Cr}(\mathrm{III})$ or $\mathrm{Cr}(\mathrm{VI})=5 \mu \mathrm{g} / \mathrm{L}, \mathrm{Fe}=2 \mathrm{mg} / \mathrm{L}\left(4 \mathrm{mg} / \mathrm{L} \mathrm{Fe}(\mathrm{OH})_{3}\right), \mathrm{I}=0.01 \mathrm{M}$, using diffuse layer model of Dzombak and Morel [15]

In contrast, $\mathrm{Cr}(\mathrm{VI})$ will be virtually $100 \%$ soluble above $\mathrm{pH} 8.0$, while at $\mathrm{pH} 2-6$ less than $10 \%$ of $\mathrm{Cr}(\mathrm{VI})$ is soluble (Figure 11). Sorption of $\mathrm{Cr}(\mathrm{VI})$ to iron oxides or hydroxides starts to become highly significant (> 50\%) below about $\mathrm{pH}$ 7. $\mathrm{Cr}(\mathrm{VI})$ also forms no significant precipitates at levels encountered in potable water and does not strongly bind to natural organic matter. Hence, $\mathrm{Cr}(\mathrm{VI})$ is generally present in drinking water as a soluble anion, and its potential human toxicity is a much greater concern than $\mathrm{Cr}(\mathrm{III})$. Although we analyzed total chromium in these water resources, $\mathrm{Cr}(\mathrm{VI})$ is the main ion with increasing $\mathrm{pH}$ 6 to $\mathrm{pH} 8$ (Figure 11). Based on Morry [12] hexavalent chromium is 50 to $90 \%$ of the total chromium in many water supplies.

Hexavalent chromium is classified as a known human 
carcinogen by inhalation routes of exposure [16,17]. Because of the lack of data on carcinogenicity of hexavalent chromium to humans via oral routes of exposure from drinking water, National Toxicology Program [18] and Stout et al, [19] concluded that hexavalent chromium, as sodium dichromate dihydrate, in drinking water caused oral cancers in rats and cancer of the small intestine in mice. Ingestion of hexavalent chromium in drinking water by human changes hexavalent chromium to trivalent chromium with the formation of Cr-DNA adducts and other DNA damage resulting in mutagenesis, cell proliferation and tumor formation in the GI tract California [20, 21, 22, 23] (Figure 12).

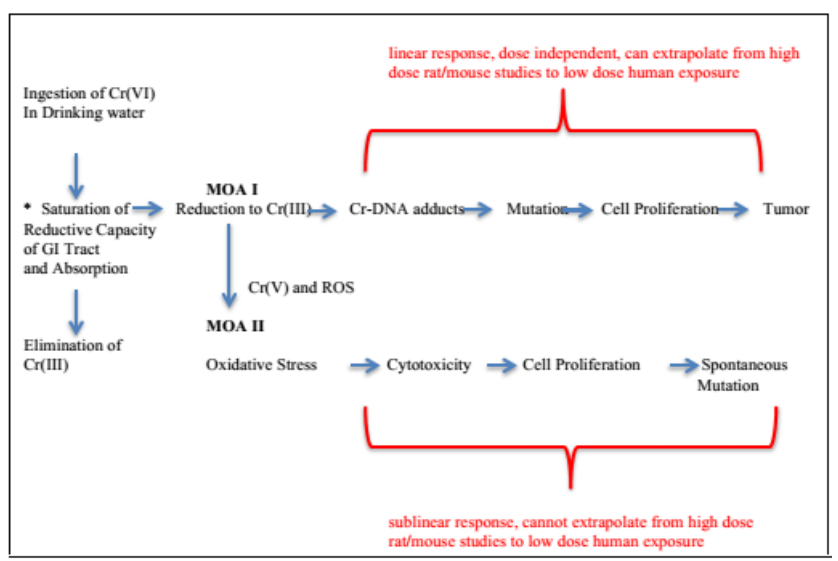

Figure 12. Cancer effects in humans from ingestion of hexavalent chromium in drinking water [20, 21, 22, 23].

The World Health Organization (WHO) in 2003 [10]set the provisional guideline value for total chromium in drinking water at $50 \mu \mathrm{g} / \mathrm{l}$. But this regulation was set prior to the publication of the NTP and other recent health effects studies. A non-enforceable Public Health Goal (PHG) for hexavalent chromium of $0.02 \mu \mathrm{g} / \mathrm{l}(20 \mathrm{ppt})$ was issued in July 2011 by California OEHHA [20], and California will now proceed with setting an MCL for hexavalent chromium.

Based on WHO [10] guideline for total chromium two water samples, $60.61 \mu \mathrm{g} / \mathrm{l}, 55.94 \mu \mathrm{g} / \mathrm{l}$ were more than $50 \mu \mathrm{g} / \mathrm{l}$ and another two samples with $48.95 \mu \mathrm{g} / \mathrm{l}$ were around to this guideline. Moreover, based on Public Health Goal for hexavalent chromium all samples were higher than $0.02 \mu \mathrm{g} / \mathrm{l}$. So, in this area individuals should be medical check-up for cancer risk of gastrointestinal (GI) tissue and remediation of $\mathrm{Cr}(\mathrm{VI})$ in potable water must be considered.

\subsection{Remediation}

It is not clear how much of total chromium in the groundwater are $\mathrm{Cr}(\mathrm{III})$ or $\mathrm{Cr}(\mathrm{VI})$, but it is clear, and $\mathrm{Cr}(\mathrm{III})$ could be converted to $\mathrm{Cr}(\mathrm{VI})$ in oxidant aquifer and by added oxidants (such as potassium permanganate) and disinfectants (chlorine, chloramine) used in the treatment plant. Some of the most common remediation strategies utilize oxidation-reduction reactions, converting $\mathrm{Cr}(\mathrm{VI})$ to $\mathrm{Cr}(\mathrm{III})$. Reducing $\mathrm{Cr}(\mathrm{VI})$ in water resource will be achieved by physical (ion exchange), chemical, and biological reduction processes. Among these processes, chemical remediation is a cost-effective and convenient plan for unconfined aquifers. Injection of an electron donor such as hydrogen sulfide $\left(\mathrm{H}_{2} \mathrm{~S}\right)$ [24], sodium dithionite $\left(\mathrm{Na}_{2} \mathrm{~S}_{2} \mathrm{O}_{4}\right)$ [25], sodium metabisulfite $\left(\mathrm{NaHSO}_{3}\right)$, calcium metabisulfite $\left(\mathrm{CaHSO}_{3}\right), \mathrm{FeSO}_{4}$, calcium polysulfide $\left(\mathrm{CaS}_{5}\right)$ [26], $\mathrm{Fe}(\mathrm{II})$ [27], $\mathrm{Fe}(0)$ [28], or tin(II) chloride $\left(\mathrm{SnCl}_{2}\right)$. Field testing has shown that sodium dithionite $\left(\mathrm{Na}_{2} \mathrm{~S}_{2} \mathrm{O}_{4}\right)$, injected into an unconfined aquifer, successfully reduces chromate $[29,30]$. Existing wells or trenches can be used for chemical delivery. A more precise method of delivering liquid chemicals to the subsurface uses high-pressure injection technology, also called jetting [31]. Monitoring indicated that the treatment zone remained anoxic after 2 years and that chromate remained undetected. Additionally, operation and maintenance costs are low and no pumping and aboveground treatment are required.

\section{Acknowledgements}

We would like to thank peoples who supported us logistically and assisted us in the field. The authors are grateful to anonymous reviewers for their suggestions and recommendations.

\section{REFERENCES}

[1] GSI, "Geology map of Sabzevar," Geological Survey of Iran, 1989.

[2] GSI, "Geology map of Jajarm," Geological Survey of Iran, 1992.

[3] D. Tarboton, "Hydrology Research Group," [Online]. Available: http://hydrology.usu.edu/dtarb/. [Accessed 2017].

[4] M. K. Noghreyan, Evolution Geochmique, Mineralogique et structurale d' UN edifice ophiolitique singulier: Le massif de Sabzevar (partie centrale), NE DE,l' Iran, Universite de Nancy, 1982.

[5] Rai, D; Saas, B M; Moore, D A, "Chromium(III) Hydrolysis Constants and Solubility of Chromium(III) Hydroxide," Inorganic Chemistry, vol. 26, no. 3, p. 345, 1987.

[6] J. N. Butler, Ionic Equilibrium, NY: Addison-Wesley, 1967.

[7] J. D. Hem, "Reactions of Metal Ions at Surfaces of Hydrous Iron Oxide," Geochimica et Cosmochimica Acta, vol. 41, p. 527, 1977.

[8] C. Health, "Guidelines for Canadian Drinking Water 
Quality—Summary Table. Water and Air Quality Bureau, Healthy Environments and Consumer Safety Branch," Health Canada, Ottawa, Ontario, 2017.

[9] NPDWR. [Online]. Available: https://www.epa.gov/ground-water-and-drinking-water/nati onal-primary-drinking-water-regulations. [Accessed 2017].

[10] WHO, "Chromium in Drinking Water- Background Document for Development of WHO Guidelines for Drinking-Water Quality," World Health Organization, Geneva Switzerland, 2003.

[11] EPA, Manual for the Certification of Laboratories Analyzing Drinking Water, Fifth Edition ed., 2005.

[12] B. Morry, "Public Health Goal for Chromium in Drinking water," California Environmental Protection Agency, 1999.

[13] Di Bona, K; Love, S; Rhodes, N R; McAdory, D; Sinha, S H; Kern, N; Kent, J; Strickland, J; Wilson, A; Beaird, J; Ramage, J; Rasco, J F; Vincent, J B, "Chromium is not an Essential Trace Element for Mammals: Effects of a 'Low-Chromium' Diet.," Journal of Biological Inorganic Chemistry, vol. 16, no. 3, p. 381, 2011.

[14] Icopini, G A; Long, D T, "Speciation of aqueous chromium by use of solid-phase extractions in the field.", Environmental Science \& technology, vol. 36, no. 13, p. 2994, 2002.

[15] Dzombak, D. A.; Morel, f.M. M; Surface Complexation Modeling: Hydrous Ferric Oxide., New York: Wiley-Interscience, 1990.

[16] USEPA, "Methods to Develop Inhalation Cancer Risk," U.S. Environmental Protection Agency, 2011.

[17] IARC, "IRAC Monographs on the Evaluation of Carcinogenic Risks to Humans: Volume 49: Chromium, Nickel and Welding.," Lyon France, 1990.

[18] NTP, "Technical Report on the Toxicology and Carcinogenesis Studies of Sodium Dichromate Dihydrate," National Toxicology Program, 2008.

[19] Stout, M.D., Herbert, R.A., Kissling, G.E., Collins, B.J., Travlos, G.S., Witt, K.L., Melnick, R.L., Abdo, K.M., Malarkey, D.E. \& Hooth, M.J., "Hexavalent Chromium is Carcinogenic to F344/N Rats and B6C3F1 Mice after Chronic Oral Exposure.," Environmental Health Perspect, vol. 117, no. 5, p. 716, 2009.

[20] OEHHA, "Final Technical Support Document on Public Health Goal for Hexavalent Chromium in Drinking Water," OEHHA, 2011.
[21] A. Zhitkovich, "Chromium in Drinking Water: Sources, Metabolism, and Cancer Risks," Chemical Research in Toxicology, vol. 24, no. 10, p. 1617, 2011.

[22] McCarroll, N., Keshava, N., Chen, J., Akerman, G., Kligerman, A. \& Rinde, E., "An Evaluation of the Mode of Action Framework for Mutagenic Carcinogens Case Study II: Chromium (VI)," Environmental and Molecular Mutagenesis, vol. 51, no. 2, p. 89, 2010.

[23] McNeil, L; Mclean, J; Edwards, M; Park, J; "State of the Science of Hexavalent Chromium in Drinking Water," Water Research Foundation 6666 W, Denver, 2012.

[24] Thornton, E.C. and Amonette, J.E., "Hydrogen sulfide gas treatment of $\mathrm{Cr}(\mathrm{VI})$ - contaminated sediment samples from a plating-waste disposal site-implications for in-situ remediation," Environmental Science and Technology, vol. 33, no. 22, p. 4096-4101., 1999.

[25] Fruchter, J.S., Cole, C.R., Williams, M.D., Vermeul, V.R., Amonette, J.E., Szecsody, J.E.,Istok, J.D., and Humphrey, M.D., "Creation of a subsurface permeable treatment barrier using in situ redox manipulation," Groundwater Monitoring and Remediation Review, 2000.

[26] Jacobs, J., Hardison, R.L., and Rouse, J.V., "In-situ remediation of heavy metals using sulfur-based treatment technologies," Hydrovisions, vol. 10, no. 2, p. 1-4, 2001.

[27] Seaman, J.C., Bertsch, P.M., and Schwallie, L., "In-situ $\mathrm{Cr}(\mathrm{VI})$ reduction within coarse-textured, oxide-coated soil and aquifer systems using Fe(II) solutions," Environmental Science and Technology, vol. 33, no. 6, p. 938-944., 1999.

[28] Ponder, S M; Darab, J G; Mallouk, T E, "Remediation of $\mathrm{Cr}(\mathrm{VI})$ and $\mathrm{Pb}(\mathrm{II})$ aqueous solutions using supported, nanoscale zero-valent iron," Environmental Science and Technology, vol. 34, no. 12, p. 2564-2569, 2000.

[29] USDOE, "In situ redox manipulation, Innovative Technology Summary Report DOE/EM-0499," USDOE, 2000.

[30] Vermeul, Vince, R., Williams, Mark D., Szecsody, Jim E., Fruchter, and John S., "In Situ Redox Manipulation Pilot Field Test: Remedial Design Support for ISRM Barrier Deployment," Frontier Hard Chrome Superfund Site, Vancouver, WA, 2002.

[31] J. Jacobs, "In-situ Liquid Delivery Systems for Chemical Oxidation, Bioremediation and Metals Stabilization, Association for Environmental Health and Sciences," in 11th Annual West Coast Conference. in Contaminated Soils, Sediments, and Water, Abstracts, San Diego, California, 2001. 